\title{
The Bolus Dose Estimation Formula for Carbohydrate-to-Insulin Ratio, CIR, and Correction Factor (CF) are more Accurately Determined from Each Other than Total Daily Dose (TDD)
}

\author{
Allen B King* and Jillaine S Socha \\ Diabetes Care Center, USA
}

Submission: June 12, 2017; Published: June 27, 2017

*Corresponding author: Allen B King, Diabetes Care Center, Salinas, CA, USA, Tel: 831-769-9355; Email: aking@diabetescarecenter.com

\begin{abstract}
Determination of the bolus dosing factors, CIR and CF, are important for the initiation and subsequent evaluation of insulin management. The current accepted estimation formulas, $\mathrm{CIR}=450 / \mathrm{TDD}$ and $\mathrm{CF}=1700 / \mathrm{TDD}$ [1], were retrospectively inferred from uncontrolled clinical observations [2]. Prospective controlled studies [3,4] have suggested that the bolus dosing factors calculated from these formulas provided too little insulin. Further, the precision could be improved by calculating one factor, if established, from the other than from the TDD. Here we provide further support for our previous findings.
\end{abstract}

Keywords: Carbohydrate to insulin ratio; Correction factor; Bolus dose estimation formulas; Multiple daily injections; Insulin pump; Insulin Abbreviations: CIR: Carbohydrate to Insulin Ratio; CF: Correction Factor; TDD: Total Daily Dose

\section{Methods}

We retrospectively selected the last 11 patients that completed titration of their basal dose/rate and bolus dosing factors. Our routine office procedure is to establish the basal dose first and then the bolus dosing ratios. In these patients, the basal dose of long acting insulin or pump-delivered basal rate was adjusted to a basal glucose target $(70-150 \mathrm{mg} / \mathrm{dl})$ using frequent plasma glucose measurements and sequentially omitted meals. Then the CIR (grams of carbohydrate/U) was determine by a liquid mixed meal (BOOST®HIGH PROTEIN) (Carbohydrate 53\%; Protein 25\%; Fat 22\%). The dose of rapid acting insulin was adjusted to return the second to the fourth hour glucose to $\pm 20 \%$ of the pre-meal. The CF (mg/dl/U) was independently determined by allowing the basal glucose to rise $(150-300 \mathrm{mg} / \mathrm{dl})$ by reducing the basal insulin $30-50 \%$. The $\mathrm{CF}$ was determined during a non-dawn phenomenon portion of the day and was defined by the decline in glucose by the second to the fourth hour divided by the dose of insulin. A linear regression was then constructed with the y intercept set at zero. The adjusted $\mathrm{r}$ and the $\mathrm{R}^{2}$ value were also determined.
Results

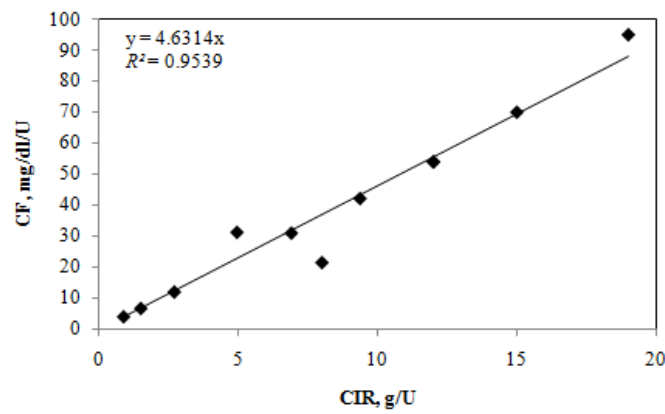

Figure 1: The Correction Factor (CF), in $\mathrm{mg} / \mathrm{dl} / \mathrm{U}$, compared to the Carbohydrate to Insulin Ratio (CIR), in grams of carbohydrates/ $U$, in $11 \mathrm{~T} 1$ or T2 diabetes on multiple daily injections or insulin pump in which the bolus dosing factors were determined by set carbohydrate meal and created hyperglycemia, frequent glucose determinations and after the total basal dose was established.

The mean of 11 ( 6 women) consecutive patients, both T1 and T2, age was 57 years; weight, $88.4 \mathrm{~kg}$; and $\mathrm{HbA1c}, 7.2 \%$. 
The range of TDD was 15 to $125 \mathrm{U} / \mathrm{d} . \mathrm{CF}=4.63 \times \mathrm{CIR}\left(\mathrm{R}^{2}=0.954\right)$ (Figure 1$), \mathrm{CIR}=257 / \mathrm{TDD}\left(\mathrm{R}^{2}=0.418\right)$ (Figure 2$), \mathrm{CF}=1230 / \mathrm{TDD}$ $\left(\mathrm{R}^{2}=0.578\right), \mathrm{CIR}=99.2 / \mathrm{TBD}\left(\mathrm{R}^{2}=0.665\right)$ and Total Basal Dose (TBD)/TDD $=0.400\left(\mathrm{R}^{2}=0.732\right)$.

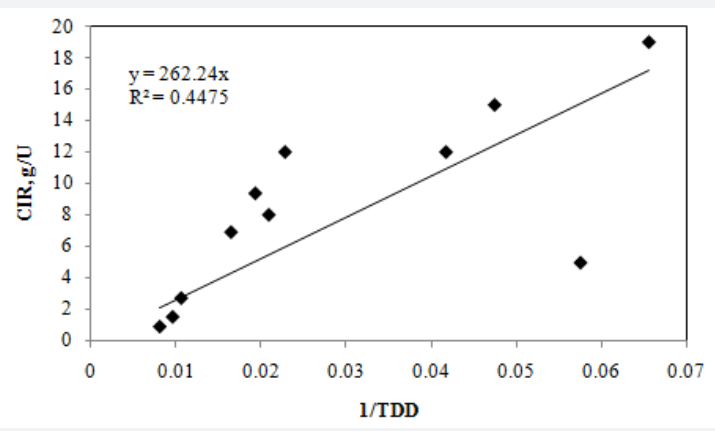

Figure 2: The Carbohydrate to Insulin Ratio (CIR), in grams of carbohydrates/U, compared to the reciprocal of the Total Daily Dose (TDD) in $11 \mathrm{~T} 1$ or T2 diabetes on multiple daily injections or insulin pump in which the bolus dosing factor was determined by set carbohydrate meal, frequent glucose determinations and after the total basal dose was established.

\section{Conclusion}

These observations confirm previous findings that a more precise formula for CIR would be CIR $=300 / \mathrm{TDD}$ and not 450 / TDD. In prospective studies in which the CIR was also carefully determined, Kuroda et al. [5] and Alcantara-Aragon et al. [6] reported that the CIR formula should be about CIR=300/TDD. We also conclude that an even more precise estimation of bolus dosing factors could be provided by the proportionality between the factors and not in formulas utilizing the TDD. If the CIR is established, then the $\mathrm{CF}$ could be calculated by $\mathrm{CF}=4.5 \mathrm{x}$ CIR. If the $\mathrm{CF}$ is established, then $\mathrm{CIR}=\mathrm{CF} / 4.5$. TDD is not accurately known until after the insulin titration is complete and does not provide reliable information during titration. Total basal dose and the bolus dosing factors are measurements of insulin sensitivity. TDD is not exactly. It includes the total bolus dose which in turn also is a measurement of the bolus amount given for a day's total amount of carbohydrates eaten and given for episodic hyperglycemia. It has been suggested that CIR and CF are not related units and therefore must be calculated separately [2]. We would propose that they are the same.

CF units are $\Delta$ glucose/U. CIR units are grams of carbohydrate/U which could be rewritten as the anticipated $\Delta$ glucose/U. Although this study is small and retrospective, the findings are supported by the close agreement with our prior study $[3,4]$ and the wide range of TDD, TBD, CF and CIR values. It is evident that the current guidelines for insulin dosing need to be changed and more bolus insulin needs to be given.

\section{References}

1. Grunberger G, Abelseth JM, Bailey TS, Bode BW, Handelsman Y, et al. (2014) Consensus statement by the American Association of Clinical Endocrinologists/American College of Endocrinology Insulin Pump Management Task Force. Endocr Pract 20(5): 463-489.

2. Davidson PC, Hebblewhite HR, Steed RD, Bode BW (2008) Analysis of guidelines for basal-bolus insulin dosing: basal insulin, correction factor, and carbohydrate-to-insulin ratio. Endocr Pract 14(9): 10951101.

3. King AB, Armstrong DU (2007) A prospective evaluation of insulin dosing recommendations in patients with type 1 diabetes at near normal glucose control: Basal dosing. J Diabetes Sci Technol 1(1): 3641.

4. King AB, Armstrong DU (2007) A prospective evaluation of insulin dosing recommendations in patients with type 1 diabetes at near normal glucose control: Bolus Dosing. J Diabetes Sci Technol 1(1): 4246.

5. Kuroda A, Yasuda T, Takahara M, Sakamoto F, Kasami R, et al. (2012) Carbohydrate-to-insulin ratio is estimated from 300-400 divided by total daily insulin dose in type 1 diabetes patients who use the insulin pump. Diabetes Technol Ther 14(11): 1077-1080.

6. Alcantara-Aragon V, Gonzalez C, Corcoy R, Ubeda J, Chico A (2015) Carbohydrate-to-Insulin Ratio in a Mediterranean Population of Type 1 Diabetic Patients on Continuous Subcutaneous Insulin Infusion Therapy. J Diabetes Sci Technol 9(3): 588-592.

\section{Your next submission with Juniper Publishers will reach you the below assets}

- Quality Editorial service

- Swift Peer Review

- Reprints availability

- E-prints Service

- Manuscript Podcast for convenient understanding

- Global attainment for your research

- Manuscript accessibility in different formats ( Pdf, E-pub, Full Text, Audio)

- Unceasing customer service

Track the below URL for one-step submission https://juniperpublishers.com/online-submission.php 